\title{
HETEROGENEOUS PHENOTYPES OF JAPANESE CASES WITH A GROWTH HORMONE GENE DELETION
}

\author{
Ichiro Matsuda, ${ }^{1}$ Akira Hata, ${ }^{1}$ Yoshihiro Jinno, ${ }^{1,}$ * \\ Fumio Endo, ${ }^{1}$ Izumi AKaboshI, ${ }^{1}$ Yoshikazu NishI, ${ }^{2}$ \\ Shin TAKEuCHI, ${ }^{3}$ Michiko TAKeda, ${ }^{4}$ \\ and Yoshiaki OKADA ${ }^{5}$ \\ ${ }^{1}$ Department of Pediatrics, Kumamoto University Medical School, \\ Kumamoto 860, Japan \\ ${ }^{2}$ Department of Pediatrics, Hiroshima Red Cross Hospital, \\ Hiroshima 745, Japan \\ ${ }^{3}$ College of Medical Technology, Shinshu University School of \\ Medicine, Matsumoto 390, Japan \\ ${ }^{4}$ Department of Pediatrics, Onomichi General Hospital, \\ Onomichi 722, Japan, and ${ }^{5}$ Okada Private Clinic, \\ Osaka 541, Japan
}

\begin{abstract}
Summary We studied four Japanese patients with isolated growth hormone (hGH) deficiency from three different families. There was consanguinity in two of the three families, and three patients were second cousins. Each patient was homozygous for a deletion of approximately 7.5 kilobases, which included the hGH-N gene. The deletions in three patients belonging to two different families were associated with the same restriction fragment length polymorphism haplotype, while the deletion of the other patient was associated with a different haplotype. All patients were treated with injections of pituitary hGH. The response to the therapy differed among them, that is, two patients belonging to different families showed a poor response together with the presence of anti-hGH antibodies, while the other two patients belonging to the same family showed a rather good response together with the absence of such antibodies. It is suggested that the production of anti-hGH antibodies is not solely due to the gene deletion, but that an unknown immunological disposition might also be involved.
\end{abstract}

Received August 13, 1987; Accepted September 1, 1987

* Present address: Department of Human Genetics, Nagasaki University School of Medicine, Nagasaki 852, Japan 


\section{INTRODUCTION}

Single gene disorders of isolated human growth hormone $(\mathrm{hGH})$ deficiency are classified into three different types: autosomal recessive (type I), autosomal dominant (type II) and X-linked recessive (type III) (Phillips III, 1983). Illig (1970) and Illig et al. (1971) distinguished a subgroup among type I patients, referred to type I-A, on clinical grounds. Later, Phillips III et al. (1981) clarified, based on restriction endonuclease analysis, that the Swiss patients described by Illig et al. (1970) were homozygous for a deletion of approximately 7.5 kilobases $(\mathrm{kb})$ of DNA which contained the normal hGH gene (hGH-N). Subsequent studies disclosed the disease in children in Austria (Phillips III, 1983), Argentina (Phillips III, 1983; Rivarola et al., 1984), Japan (Phillips III, 1983; Nishi et al., 1984), Italy (Braga et al., 1985), Israel (Laron et al., 1985) and France (Goossens et al, 1986). The phenotypes of the affected subjects differed in several respects. We describe four additional Japanese patients from three different families with a hGH-N gene deletion.

\section{SUBJECTS AND METHODS}

Subjects. Four Japanese patients with type I-A isolated hGH deficiency from three different families were studied with informed consent. Their clinical and laboratory data are presented in Table 1. Cases 1 and 2 were siblings. The clinical record of case 4 was reported elsewhere (Mori et al., 1981). Both the parents of cases 1 and 2 and the parents of case 3 were second cousins. The parents of case 4 were unrelated. All four patients received hGH (Crescormone ${ }^{\circledR}$; AB Kabi, Stockholm, Sweden), for periods of three months to over 10 years, depending on the response. Plasma hGH, TSH, FSH, ACTH and prolactin were measured with commercial radioimmunoassay kits. Plasma from the patients was repeatedly examined for the presence of anti-hGH antibodies by the method of Roth et al. (1964). Clinical and laboratory data for the first patient described in Japan (Nishi et al., 1984) are included in Table 1 for a reference.

DNA probe. cDNA of hGH, a kind gift from Dr. P.H. Seeburg, was prepared by the cleared lysis procedure and purified on $\mathrm{CsCl}$ gradients. The internal 490 base pair $P v u I I$ fragment was labeled by nick translation, with a final specific activity of $1 \times 10^{8} \mathrm{cpm} / \mu \mathrm{g}$.

Preparation of DNA and blot hybridization. Total genomic DNAs were extracted from lymphoid cell lines established with the Epstein-Barr virus (Matsuda et al., 1977) or whole blood by the method of Kunkel et al. (1977). DNA samples were completely digested using restriction enzymes BamHI, HindIII, BglII, HincII and $M s p \mathrm{I}$, and then fractionated by electrophoresis on $0.8 \%$ agarose gels. Blotting onto nitrocellulose filters was carried out by the method of Southern (1975). The 


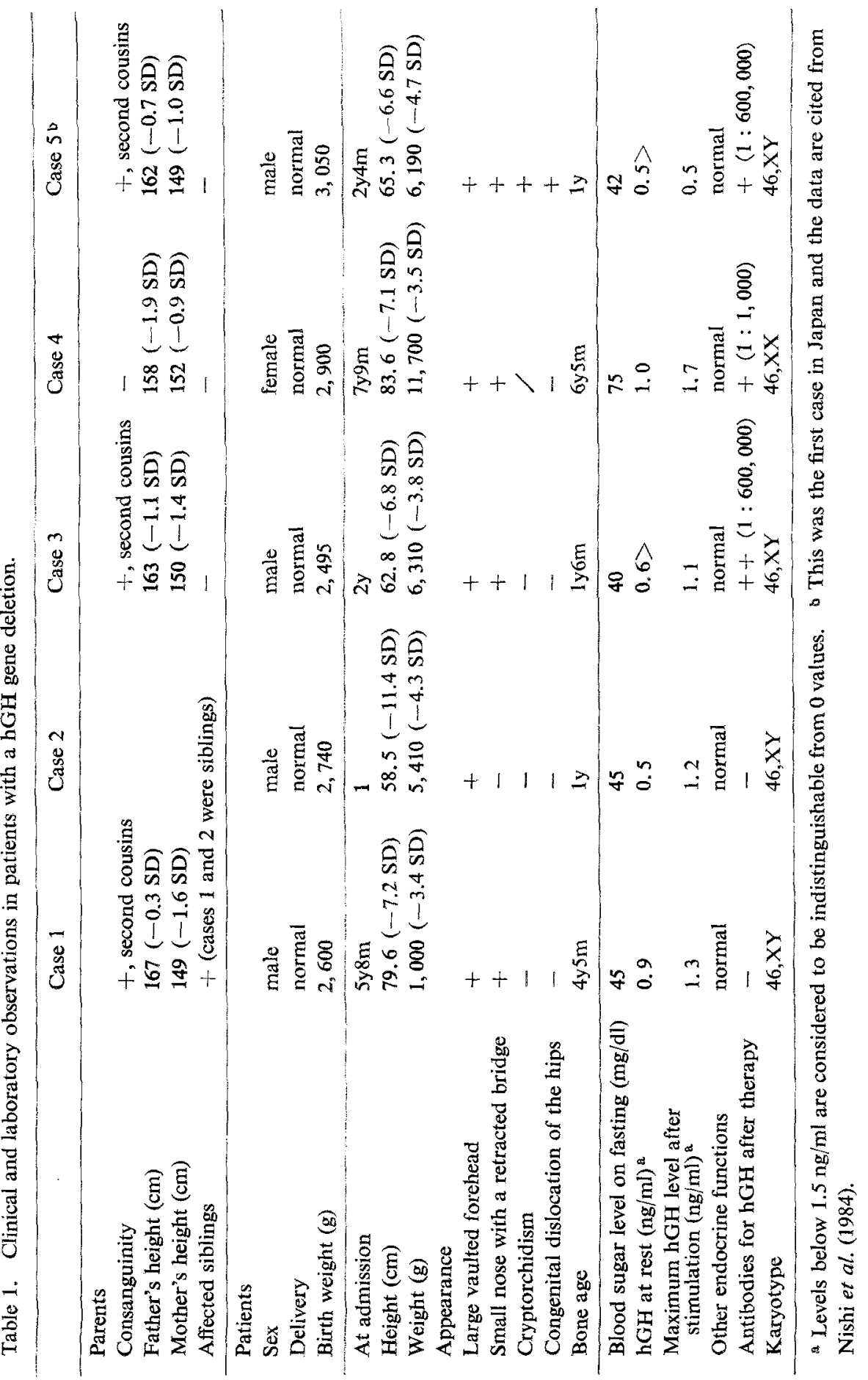


hybridization buffer contained $50 \%$ formamide, $5 \times \mathrm{SSC}, 10 \times$ Denhardt's solution, $50 \mathrm{~mm}$ sodium phosphate ( $\mathrm{pH} 6.5$ ), $0.1 \%$ sodium dodecyl sulphate (SDS) and 200 $\mu \mathrm{g} / \mathrm{ml}$ of denatured salmon sperm DNA. Hybridization was performed at $42^{\circ} \mathrm{C}$ for $24 \mathrm{hr}$. Each filter was washed three times for $5 \mathrm{~min}$ with excess $1 \times \operatorname{SSC}(0.3 \mathrm{M}$ $\mathrm{NaCl}, 0.03 \mathrm{M}$ Trisodium citrate) $/ 0.1 \%$ SDS at room temperature and then washed for $1 \mathrm{hr}$ with $0.1 \times \mathrm{SSC} / 0.1 \% \mathrm{SDS}$ at $56^{\circ} \mathrm{C}$. The filter was then exposed to an $\mathrm{X}$ ray film, with a Dupont Lightning-plus intensifying screen, at $-80^{\circ} \mathrm{C}$ for $24 \mathrm{hr}$.

Enzymes and chemicals. The restriction enzymes were purchased from Takara Shuzo Co. and Toyobo Co., and E. coli DNA polymerase 1 was from New England Biolabs. $\left[\alpha^{-32} \mathrm{P}\right] \mathrm{dCTP}(3,000 \mathrm{Ci} / \mathrm{mmol})$ was obtained from Amersham. The nitrocellulose filters were from Schleicher and Schuell.

\section{RESULTS}

\section{Clinical course}

For case 1 , treatment with hGH injections was initiated at the age of 5 . The initial dose of hGH was $4 \mathrm{U} /$ week, and later the dose was increased gradually to 6 , 8,12 and $16 \mathrm{U} /$ week at the age of 10,13 and 14 , respectively. At the age of 13 when his height was $124.7 \mathrm{~cm}$ which corresponds to the height at the age of 8 , he developed clinical signs of puberty and so cyproterone acetate (an anti-androgenic drug) was administered for a while in order to delay pubertal maturation. At the age of 14 , his serum testosterone level was within normal adult limits and the development of his genitalia corresponded to stage III of Tanner's classification. Repeated examinations for anti-hGH antibodies gave negative results consistently. Generally speaking, he showed a rather good response to the treatment (Fig. 1A). Case 2 was the younger brother of case 1 . He also showed a good response to $4 \mathrm{U} /$ week hGH injections, and anti-hGH antibodies were never detected throughout the repeated examinations (Fig. 1A).

For case 3, we started giving injections of $4 \mathrm{U} /$ week of $\mathrm{hGH}$ at the age of 5 , and his height increment was $1 \mathrm{~cm}$ per 1 month during 3 months of the therapy (Fig. 1A). After that, his height increment became almost unmeasurable and subcutaneous fat tissue atrophy was observed on the buttocks at the site of injections. His serum anti-hGH antibodies titer was increased to $1: 600,000$. The patient and his parents refused the continuation of the treatment.

Case 4 , a female patient, was treated with $6 \mathrm{U} /$ week hGH injections at the age of 8 . Her height increment was $4.3 \mathrm{~cm}$ during the first 6 months of the therapy, while during the next 6 months of the therapy her height increment was only $0.6 \mathrm{~cm}$ (Fig. 1B). Similar to in case 3, she developed subcutaneous fat tissue atrophy around the buttocks after the repeated injections. Her anti-hGH antibodies titer was positive, being $1: 1,000$, and remained highly positive even 3 years after discontinuation of the therapy. Soon after her treatment was discontinued when she 


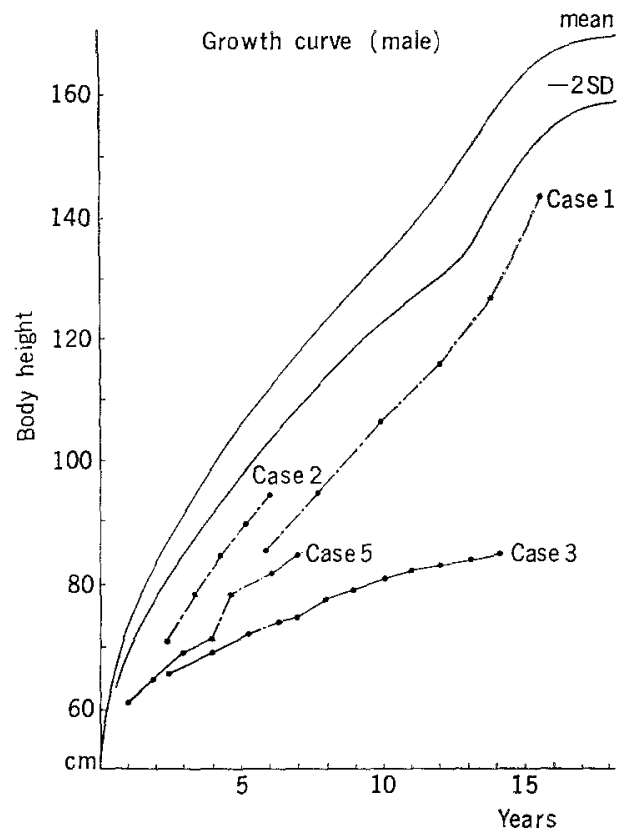

A

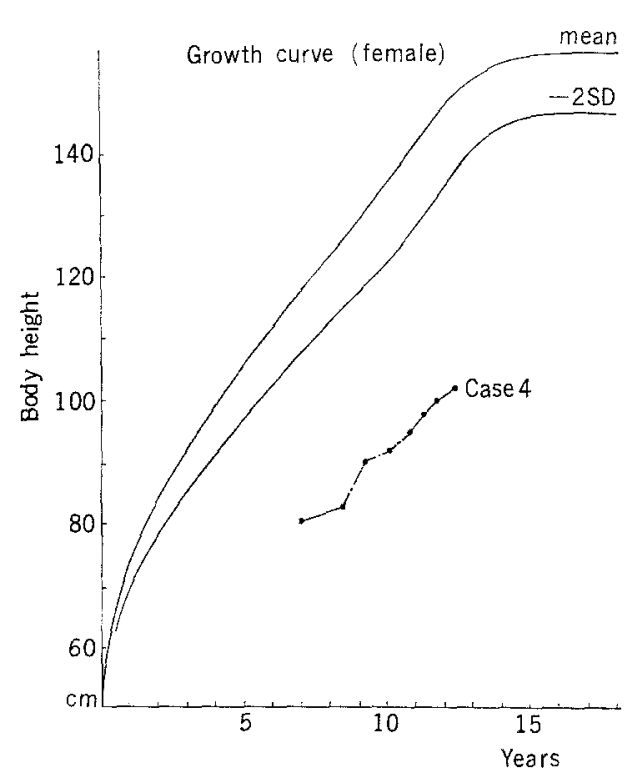

B

Fig. 1. A: Growth curve of case 1,2,3 and 5 (males). B: Growth curve of case 4 (female).

was 10 years and 8 months old, pubertal signs including stage IV breasts and the menarche were observed.

\section{Restriction endonuclease analysis}

The autoradiogram patterns of DNAs after BamHI digestion of cultured lymphoid cells from each patient showed the absence of the $3.8 \mathrm{~kb}$ fragment that contains the hGH-N gene. A representative pattern for cases 1,2,3 and 4, and a reference case with a hGH gene deletion (Nishi et al., 1984) is shown in Fig. 2. All tested parents appeared to have approximately half of the $3.8 \mathrm{~kb}$ DNA fragment, indicating a heterozygous state. Other DNA fragments of $8.5,6.7,5.3$, and 3.0 plus $1.2 \mathrm{~kb}$, which correspond to the human chorionic somatomammotropin-like (hCS-L), hChSB, hCS-A and hGH-V genes (Seeburg, 1982), were all observed in each patient. The results of HincII digestion confirmed the absence of the hGH-N gene (Fig. 3). None of the affected patients showed the hybridizing 4.5 or $6.7 \mathrm{~kb}$ fragment, which is found in normal samples, depending on the presence or absence of a polymorphic restriction site immediately $5^{\prime}$ of the first exon of the gene (Laron et al., 1985).

Digestion with HindIII yielded three hybridizing fragments in normal samples; 26,23 and $16 \mathrm{~kb}$ in length. The largest one, the $26 \mathrm{~kb}$ fragment, contains the hGH$\mathrm{N}$ and hCS-L genes. The 23 and $16 \mathrm{~kb}$ fragments contain the hCS and hGH-V 


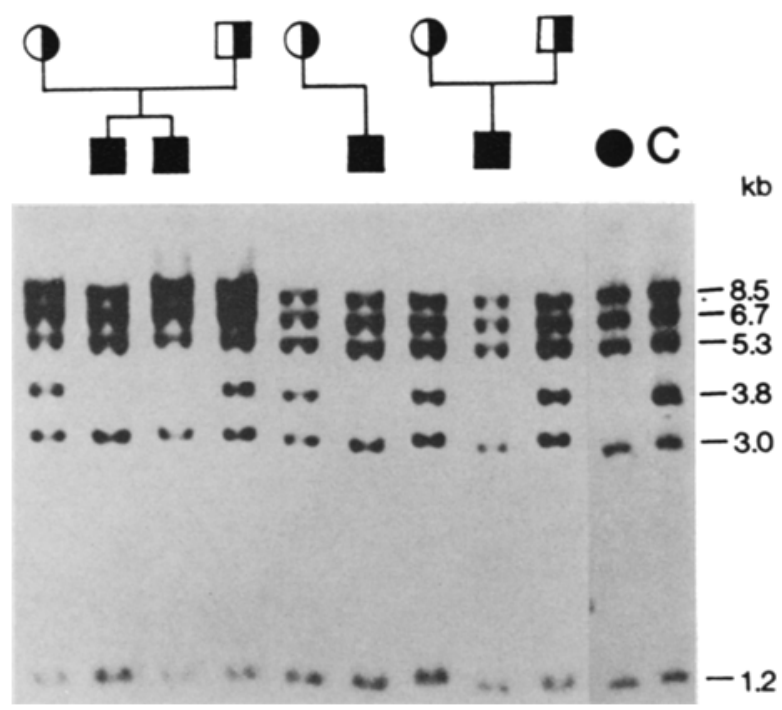

Fig. 2. Restriction endonuclease BamHI "signatures" from members of four Japanese families with isolated growth hormone deficiency type $1 \mathrm{~A}$ (case 1, 2, 3, 5 and 4; at far right is a normal control). All affected children lack the $3.8 \mathrm{~kb}$ fragment which contained hGH-N gene.

genes, respectively (Phillips III, 1983). All patients showed the absence of the 26 $\mathrm{kb}$ gene but the presence of a fragment of $18.5 \mathrm{~kb}$ in length (Fig. 3). This result indicated that the deletion in each patient was $7.5 \mathrm{~kb}$ in length and that it contained the hGH-N gene. The hCS-L gene appeared to be intact, when the observation on BamHI digestion was taken into account.

Digestion with $B g l \mathrm{II}$ and $M s p$ I permitted assignment of restriction fragment length polymorphism (RFLP) haplotypes for individual growth hormone gene clusters. As shown in Fig. 3 and Table 2, cases 1, 2 and 4 had the same haplotype as that of the reference case (Nishi et al., 1984), but case 3 had a different haplotype.

\section{DISCUSSION}

The hGH-N gene was analyzed in our four patients by the methods described previously (Phillips et al., 1981; Rivarola et al., 1984; Nishi et al., 1984; Laron et al., 1985). The deletion size and RFLP haplotype for the hGH gene clusters in cases 1,2 and 4, and a reference case were similar to those of an oriental Jewish family (Family IV in Laron et al., 1985), while the deletion and haplotype of case 3 was similar to those of Swiss, Argentinian (Phillips, 1983) and other oriental Jewish families (Families I, II and III in Laron et al., 1985). In the present study, only a rough estimation of the deletion length of the gene was made. Further precise analysis is required to determine whether the gene defect with the observed similar 


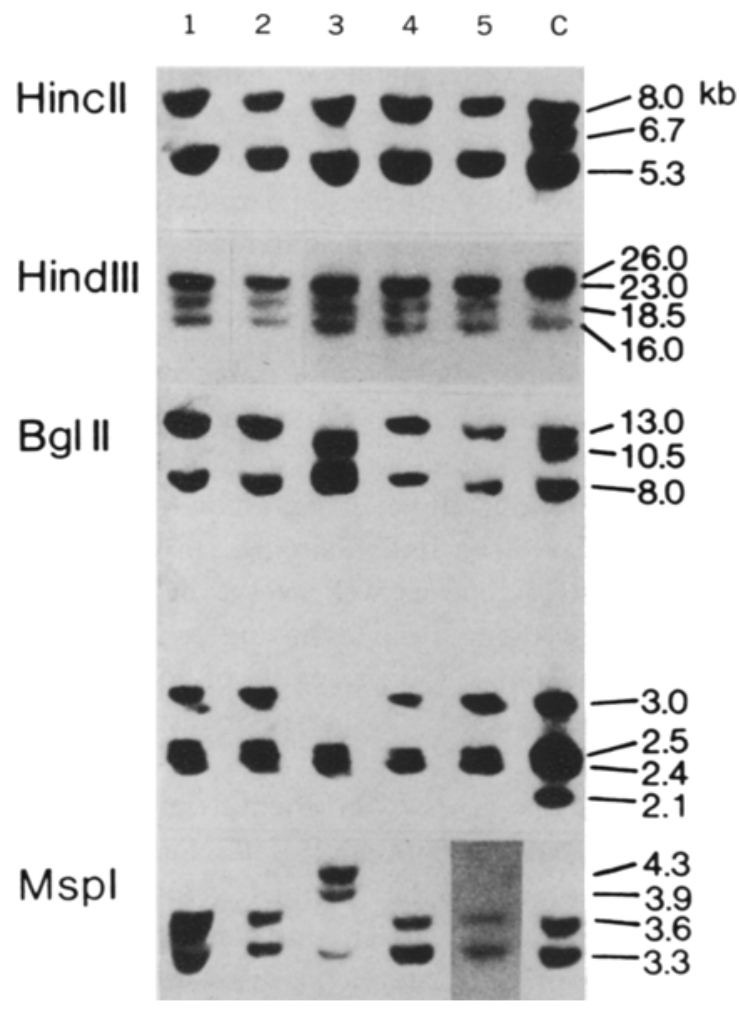

Fig. 3. Signatures of five children with isolated growth hormone deficiency type $1 \mathrm{~A}$ after digestion with HincII, HindIII, BglII, and MspI (case 1, 2, 3, 4 and 5; at far right is a normal control). All affected children lack $6.7 \mathrm{~kb}$ fragment by HincII digestion. They showed presence of $18.5 \mathrm{~kb}$ fragment and absence of $26 \mathrm{~kb}$ fragment by HindIII digestion. Two different RFLP haplotypes are seen in the children by the $B g l I I$ and $M s p I$ digestion.

Table 2. Restriction fragment length polymorphism haplotypes of the patients with a growth hormone gene deletion.

\begin{tabular}{lccccccc}
\hline & BamHI & Hincll & HindIII & BglIIA & BglIIB & MspIA & MspIB \\
\hline Case 1 & Del b & Del & 18.5 & 13.0 & 3.0 & 3.6 & 3.3 \\
Case 2 & Del & Del & 18.5 & 13.0 & 3.0 & 3.6 & 3.3 \\
Case 3 & Del & Del & 18.5 & 10.5 & 8.0 & 4.3 & 3.9 \\
Case 4 & Del & Del & 18.5 & 13.0 & 3.0 & 3.6 & 3.3 \\
Case 5 & Del & Del & 18.5 & 13.0 & 3.0 & 3.6 & 3.3 \\
\hline
\end{tabular}

a The data presented by Phillips III (1983) were confirmed in the present study. b Del, deletion. 
deletions in cases from different families are identical. Illig et al. $(1970,1971)$ reported the clinical characteristics of patients with the disease: (1) short height, particularly in relation to weight at birth, (2) early growth retardation leading to extreme dwarfism in adulthood, (3) typical facies, and (4) a high antibody titer with an initial course of hGH, rapidly followed by (5) the appearance of hGH antibodies with the arrest of growth. Cases 3 and 4, and the reference case had all these features, while cases 1 and 2 from the same family showed a better response to hGH, compared to the other cases, together with the absence of anti-hGH antibodies. The former observations were comparable to those for a Swiss family (Illig, 1970; Illig et al., 1971) and the latter were similar to those for oriental Jewish families (Laron et al., 1985).

Despite antibody formation, three Argentinian siblings continued to grow slowly (Rivarola et al., 1984). Two Italian siblings, in whom the gene deletion was $8.5 \mathrm{~kb}$, containing the hGH-N gene as well as the hCS-L gene, showed different responses to $\mathrm{hGH}$. One of them, despite having a higher anti-hGH antibodies titer, showed a fairly good response ( 50 percentile of control), while the other one, with a lower antibodies titer, showed a rather poor response (less than 3 percentile of control) (Braga et al., 1985).

As far as our cases and the cases from oriental Jewish families are concerned, the proposed hypothesis, i.e., that the presence of hGH antibodies might be the cause of the slow growth rate, seemed to be feasible. However, when the reports of Argentinian and Italian families are taken into account, it is likely that another factor may also affected the growth rate in the disease. For further discussion the nature of the anti-hGH antibodies should be clarified in each case.

Since the gene deletion was similar and the hGH preparation used was identical in each affected patient in our study, the heterogenous responses to $\mathrm{hGH}$, as to antibody production, might be due to not only the gene deletion, but also to other factors including their immunological dispositions. The absence of anti-hGH antibodies or a good response to exogenous $\mathrm{hGH}$ cannot be used to rule out isolated growth hormone deficiency in cases with a hGH gene deletion on clinical grounds.

Acknowledgment This work was supported by grants from the Ministry of Education, Science and Culture of Japan (61480219), and the Ministry of Health and Welfare, Japan.

\section{REFERENCES}

Brager, S., Phillips, J.A., III, Joss, E., Schwarz, H., and Zuppinger, K. 1985. A new type of familial growth hormone deficiency due to a $8.5 \mathrm{~kb}$ deletion within the growth hormone gene cluster. In Endocrine Genetics and Genetics of Growth. Progress in Clinical Biological Research, Vol. 200, Papadatos, C.J. and Bartsocas, C.S., eds., Alan R. Liss Inc., New York, pp. $103-111$.

Goossens, M., Brauner, R., Czernichow, P., Duquesnog, P., and Rappaport, R. 1986. Isolated growth hormone $(\mathrm{GH})$ deficiency Type $1 \mathrm{~A}$ associated with a double deletion in the human GH gene cluster. J. Clin. Endocrinol. Metab, 62: 712-716. 
Illig, R. 1970. Growth hormone antibodies in patients treated with different preparations of human growth hormone (hGH). J. Clin. Endocrinol. Metab. 31: 679-688.

Illig, R., Prader, A., Ferrandez, M., and Zachman, M. 1971. Hereditary prenatal growth hormone deficiency with increased tendency to growth hormone antibody formation, A-type of isolated growth hormone deficiency. Acta Pediatr. Scand. 60 (Suppl.): 607.

Kunkel, L.M., Smith, K.D., Boyer, S.H., Borgaonkar, D.S., Wachtel, S.S., Miller, O.J., Berg, W.R., Jones, H.W., Jr., and Rary, J.M. 1977. Analysis of human Y-chromosome specific reiterated DNA in chromosome variants. Proc. Natl. Acad. Sci. U.S.A. 74: 1245-1249.

Laron, Z., Kelijman, M., Pertzelan, A., Keret, R., Shoffner, J.M., and Parks, J.S. 1985. Human growth hormone gene deletion without antibody formation or growth arrest during treatmentA new disease entity? Isr. J. Med. Sci. 21: 999-1006.

Matsuda, I., Yamamoto, J., Nagata, N., Ninomiya, N., Akaboshi, H., Ohtsuka, H., and Katsuki, T. 1977. Cytosomal enzyme activities in cultured lymphoid cell lines. Clin. Chim. Acta 80: 483-486.

Mori, T., Naito, H., Nishikawa, H., Arakawa, K., Yoshida, Y., Takeuchi, S., and Akabane, T. 1981. Lipoatrophy observed during bGH therapy in a case of isolated growth hormone deficiency type A (Illig). Shonika Shinryo (in Japanese) 44: 2035-2040.

Nishi, Y., Aihara, K., Usui, T., Phillips, J.A., III, Mallonee, R.L., and Migeon, C.J. 1984. Isolated growth hormone deficiency type 1A in a Japanese family. J. Pediatr. 104: 885-889.

Phillips, J.A., III, Hjelle, B.L., Seeburg, P.U., and Zackmann, M. 1981. Molecular basis for familial isolated growth hormone deficiency. Proc. Natl. Acad. Sci. U.S.A. 78: 6372-6375.

Phillips, J.A., III. 1983. The growth hormone (hGH) gene and human disease. In Banbury Report 14. Recombinant DNA: Application to Human Disease, Caskey, C.T. and White, R., eds., Cold Spring Harbor Laboratory, New York, pp. 305-315.

Rivarola, M.A., Phillips, J.A., III, Migeon, C.J., Heinrich, J.J., and Hjelle, B.L. 1984. Phenotypic heterogeneity in familial isolated growth hormone deficiency type 1-A. J. Clin. Endocrinol. Metab. 59: 34-40.

Roth, J., Glick, S.M., Yalow, R.S., and Berson, S.A. 1964. Antibodies to human growth hormone (hGH) in human subjects treated with hGH. J. Clin. Invest. 43: 1056-1065.

Seeburg, P.H. 1982. The human growth hormone gene family: Nucleotide sequences show recent divergence and predict a new polypeptide hormone. DNA 1: 239-249.

Southern, E.M. 1975. Detection of specific sequences among DNA fragments separated by gel electrophoresis. J. Mol. Biol. 98 : 503-517. 